\title{
Nutritional Characteristics and Quality of Eggs from Laying Hens Fed on Papaya Peel Meal Diet
}

\author{
Jein Rinny Leke ${ }^{1 *}$, Florencia Nery Sompie ${ }^{1}$, Erwin Wantasen and Trina Ekawati Tallei ${ }^{2}$ \\ Department of Animal Husbandry, Sam Ratulangi University, Manado \\ Department of Biology, Faculty of Mathematics and Natural Sciences, Sam Ratulangi University, Manado \\ Corresponding author email: rinileke@unsrat.ac.id
}

\begin{abstract}
The objectives of this study were to analyze the eggs' nutritional characteristics and quality from laying hens fed with dried papaya (Carica papaya $L$ ) peel meal diets. A total of 200 brown laying hens strain MB 402 (42 week-old) were used in this experiment. The design used in this study was a completely randomized design (CRD) consisting of 5 treatments and 4 replications ( 10 hens each). The treatments consisted of dried papaya peel meal (DPPM) $0 \%, 3 \%, 6 \%, 9 \%$ and $12 \%$. Total feeding trial was 8 weeks. The parameters recorded included egg weight ( $\mathrm{g} / \mathrm{bird}))$, egg yolk weight (g/bird), yolk index (\%), albumen index (\%), egg yolk color, egg cholesterol ( $\mathrm{mg} / 100 \mathrm{~g})$, egg crude protein (\%), egg crude fat (\%), egg white crude protein (\%), egg yellow fat (\%), eggshell calcium (\%), eggshell phosphorus (\%), blood cholesterol (mg/dl), blood LDL cholesterol (mg/dl), and blood HDL cholesterol $(\mathrm{mg} / \mathrm{dl})$ of the laying hens. The results showed that feeding birds with $12 \%$ increased egg yolk weight, egg yolk color, egg crude fat, egg yellow fat, egg cholesterol, egg shell calcium, egg shell phosphor, blood cholesterol, blood HDL. Moreover there were no significant differences in egg weight, yolk index , albumen index, egg crude protein, egg white crude protein and blood LDL. In Conclusion, DPPM diets can be fed to the laying hens up to $12 \%$ to produce eggs without negative effects on the egg quality.
\end{abstract}

Keywords: nutritional characteristics, egg quality and papaya peel

Abstrak. Penelitian ini bertujuan untuk mengetahui karakteristik nutrisi dan kualitas telur ayam MB 402 yang mengkonsumsi tepung kulit papaya dalam ransum. Penelitian ini dilakukakan menggunakan 200 ekor ayam petelur MB 402 yang berumur 42 minggu. Rancangan penelitian yang digunakan yaitu rancangan acak lengkap (RAL) yang terdiri atas 5 perlakuan dan 4 ulangan, dan tiap perlakuan terdiri atas 10 ekor ayam petelur MB 402 . Perlakuan yang diberikan yaitu : $0 \%, 3 \%, 6 \%, 9 \%$ dan $12 \%$ DPPM. Pemberian pakan perlakuan dilakukan selama 8 minggu. Variable penelitian meliputi : berat telur (g/ekor)), berat kuning telur (g/ekor), index kuning telur (\%), index putih telur (\%), warna kuning telur, kolesterol telur ( $\mathrm{mg} / 100 \mathrm{~g})$, protein kasar telur (\%), lemak kasar telur (\%), protein kasar putih telur (\%), lemak kasar kuning telur (\%), kalsium kerabang telur (\%), fosfor kerabang telur (\%), kolesterol darah (mg/dl), kolesterol darah LDL $(\mathrm{mg} / \mathrm{dl})$, and kolesterol darah HDL $(\mathrm{mg} / \mathrm{dl})$ ayam petelur. Hasil penelitian menunjukkan bahwa pemberian ransum yang dengan suplemen DPPM sampai $12 \%$ meningkatkan berat kuning telur, lemak kasar telur, lemak kasar kuning telur, kolesterol telur, kalsium kerabang telur, fosfor kerabang telur, kolesterol darah, kolesterol darah HDL, tetapi tidak berpengaruh nyata terhadap berat telur, index kuning telur, index putih telur, protein kasar telur, protein kasar putih telur dan kolesterol darah LDL. Kesimpulan dari penelitian ini yaitu : DPPMdapat digunakan dalam pakan ayam petelur MB 402 sampai $12 \%$ karena tidak memberikan pengaruh negatif pada kualitas telur.

Kata Kunci: karakteristik nutrisi, kualitas telur dan kulit pepaya

\section{Introduction}

A brown laying hen with early egg weight during the early stages of egg production is being developed mainly for the purpose of satisfying markets that require bigger sizes of eggs. Egg quality has been intimately associated with their diet and age of the birds. Aneuploidy or incorrect number of chromosomes in a cell increases in the egg with advanced reproductive age of the hen (Hassold et al. 2001). White Leghorn (WLH) chickens are already well known for their ability to produce table eggs (Bell and Weaver. 2002). Moreover, egg industries egg industries are faced with consumer needs for enriched eggs, yet low in cholesterol content.

Several studies have shown that there is a positive correlation between cholesterol concentration in the blood with an increase in the incidence of atherosclerosis, coronary heart disease (CHD), stroke, and other metabolic diseases (Willet, 2012; Rafieian-Kopaei et al. 2014). However, to reduce cholesterol contents 
is not easy without reducing egg production and weight. Dikman and Saham (2007). According to recommendation by Leeson and Summers (2005), the laying hens aged $18-32$ weeks old need $20 \mathrm{~g}$ crude protein/hen/day and $260 \mathrm{Kcal}$ $\mathrm{ME} /$ hen/day. A decrease in energy and protein intake can cause a decrease in egg production. The internal quality of an egg when it is laid (Roxana and Usturoi. 2012). The nutrition as well as management of the hens play a significant role in maintaining the quality internal of the eggs. Egg handling and the storage practices provide a significant impact on the quality of eggs until they arrive at the consumers. Eggs are an important and inexpensive source of nutrition for a balanced diet because they contain protein, vitamins and minerals that paly an important role in health. There are many factors affecting egg quality, for instance, molting induced by the age of the hen, climate, environment, and nutrition. In recent years, there are growing concerns about the quality of eggs produced (Veena et al. 2015). This quality will affect the consumer's acceptance of these eggs, and as a result of this, it is pertinent to pay adequate attention to the challenges of preserving and marketing of eggs in maintaining its quality. From the consumers' perspective, the weight of the egg is one of the important characteristics for quality eggs.

The papaya (carica papaya L.) fruit is always available throughout the year regardless of season. This fruit is a source of antioxidants, vitamin (B,pantothenis,folic acid), minerals (magnesium, potassium), and also fiber. The DPPM incorporation into feed may serve as an alternative to increase the yolk color and decrease yolk cholesterol. The use of $8 \%$ papaya leaf, for example, produced the thickest egg shell $039-0.4 \mathrm{~mm}$ of Arabian chicken called brakel kriel silver (Muharlien et al. 2015). However, there are limited information on eggs nutritional characteristics and quality through the use of papaya peel on laying hens. Therefore , this research was required to evaluate the
Nutriotional characteristics and quality of eggs from laying hens fed DPPM diet.

\section{Materials and Method}

\section{Preparation of Dried Papaya Peel Meal}

The papaya peels were washed with clean water to remove sap and dirt. They were subsequently sundried for 5 days on a clean concrete floor. On the 5th day, the peels had become dried and crispy at a constant weight, after which they were later grinded into meal.

\section{Birds, Feeding and Management}

A total of 200 42-weeks old laying hens strain MB 402 were used in this study. Before the initiation of the experiment, the average day production of the hen was $80 \%$. The hens were individually placed into 200 units of battery cage sized $120 \times 34 \times 28 \mathrm{~cm}$ (length $\mathrm{x}$ width $\mathrm{x}$ height). In the rearing system, the hens were distributed in 25 cages. Each cage, which served as treatment units, consisted of 8 hens. Each cage is equipped with feeding and drinking tools, as weel as a hollow egg nest. The usual diets were given to the hens during the flushing based on need and age. Subsequently, the hens were adapted for 2 weeks before introducing new diet. It is important to point out that at this period they were already 42 weeks old. The feeding period lasted for 8 weeks, starting from the period when the chicken were 42 to 52 weeks old, with the addition of four weeks for the purpose of acclimatization. Five dietary treatments which was made up of (R1) $0 \%$, (R2) 3\% DPPM, (R2) 3\% DPPM, (R3) 6\% DPPM dan (R4) $12 \%$ DPPM were formulated. These diets were formulated based on the ideal iso-protein ( $17 \%$ protein), iso-energy $(2800 \mathrm{kcal} / \mathrm{kg})$ and isonutritive (Table 1 ) to meet the nutritional requirements as provided by the National Research Council (1994). The chemical compositions of the DPPM diet were $25.74 \%$ crude protein, $4.52 \%$ fat, $20.06 \%$ crude fiber, $1.12 \%$ calcium, $0.47 \%$ phosphorus and 3722 of Gross Energy (GE). The different chemical 
composition of diets is shown in Table 1.The experimental birds were maintained with diets and ad libitum drinking water on a daily basis. The birds were fed two times daily at $8.00 \mathrm{am}$ and $2.00 \mathrm{pm}$. During the period of the experiment ( 8 weeks), 25 eggs were collected in the morning $(08: 00 \mathrm{~h})$ per each experimental laying hen, to determine the eggs' quality and performance. This means that up to a total of 200 eggs were sampled over the period of the 8 weeks.

The quality characteristics of the eggs included egg weight, yolk weight (Stadelman and Cotteriil, 1997: Monira et al.2003;Parmer et al. 2006). To determine the shape index the length and diameter of the eggs were measured using a digital caliper with a sensitivity of 0.001 $\mathrm{mm}$. After that, each of the egg was broken and placed on a flat surface. After five minutes, the yolk was separated from the albumen and weighted.The shells including the membrane were washed gently under flowing tap water, air-dried, and weighted after 2 hours. The thickness of the shell, diameter and height of the yolk were measured using digital caliper (Küçükyılmaz et al. 2012). The performance and quality of the eggs were measured using the Table.1. Composition of Experimental Diets

\begin{tabular}{lccccc}
\hline \multirow{1}{*}{ Nutrient } & \multicolumn{5}{c}{ Diets (\% of DPPM) } \\
\cline { 2 - 6 } Composition & R0* & R1* & R2* & R3* & R4* \\
\hline & $0 \%$ & $3 \%$ & $6 \%$ & $9 \%$ & $12 \%$ \\
Based Diet & 100 & 97 & 94 & 91 & 88 \\
DPPM & $0 \%$ & 3 & 6 & 9 & 12 \\
Crude protein (\%) & 16.38 & 16.65 & 16.94 & 17.22 & 17.51 \\
Crude Fat (\%) & 6.77 & 6.83 & 6.9 & 6.96 & 7.02 \\
Crude Fiber (\%) & 4.49 & 4.73 & 4.98 & 5.22 & 5.46 \\
Ca (\%) & 1.89 & 1.91 & 1.92 & 1.93 & 1.95 \\
P(\%) & 0.71 & 0.71 & 0.72 & 0.72 & 0.73 \\
ME (Kcal/kg) & 2802.7 & 2791.19 & 2779.68 & 2768.17 & 2768.17 \\
\hline
\end{tabular}

DPPM:=Dried Papaya Peel Meal

* Analysis by Laboratory of Nutritional Biochemistry and Fodder, Gadjah Mada University ( 2018) following formulas according to Yannakopoulus and Tserweni-Gousi (1986).

$$
\text { Yolk index }(\%)=\frac{\text { yolk height }}{\text { yolk diameter }} \times 100
$$

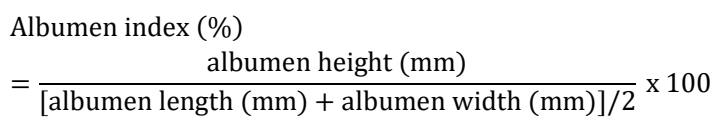

The DSM yolk color fan was used to determine the yolk (Hunton, 1987; Parmar et al. 2006; Monira et al. 2003). The yolk density was distinguished using 15 scales color index.The content of egg kolesterol was measured according to Lieberman-Burchard method. The Liebermann-Burchard known as acetic anhydride test is applied for the detection of cholestetrol. When the birds were 55 weeks old, 25 of them in each unit were individually weighed on a digital scale with (1g accuracy). After 6 hours of fasting, the blood samples were obtained, by puncturing the ulnar vein using sterile syringes and needles. As musch as $3 \mathrm{ml}$ blood aliquot was trasnferred into a sterile tube without anticoagulant and sent to Medistar Clinical Laboratory for blood cholesterol, blood HDL, Blood LDL tests. 


\section{Statistical Analysis}

Analysis of data was done using one-way analysis of variance (One-Way ANOVA) at a significant level of $P<0.05$. The means of the treatments were using Duncan's Multiple Range Test (Steel and Torrie, 1980). Software used for statistical calculations was The IBM SPSS V. 2 .

\section{Results and Discussion}

The effects of dietary papaya peel meal on eggs' performance and quality characteristics produced by laying hens are as presented in Table 2. The results showed that dried papaya peal meal has significant effect on the daily feed intake and also on egg yolk weight, egg yolk weight, egg yolk color, egg crude fat, egg yellow fat, egg cholesterol, eggshell calcium, eggshell phosphorous, blood total cholesterol, and blood HDL. The experiment did not show significant effect on egg quality characteristics such as egg weight, yolk index, albumen index, egg crude protein, egg white crude protein, and blood LDL. The results suggested that dried papaya peal meal didn't exert a negative impact on the performance of 52 week old laying hens.

One of the most important parameters for both consumers and egg producers is the egg weight (Genchev, 2012). The result of the experiment showed that the average egg weight was not significantly affected by DPPM $(46.25 \pm 22.95$ to $56.74 \pm 0.48 \mathrm{~g} / \mathrm{bird})$. The egg weight apparently will vary according to the strain of the laying hens. Breed and strain variation in the quality of eggs haves been reported to be as a result of genetic variation (Silversiders et al. 2006; Ahmad, 2013). Lalev (2013) showed that several strains of laying hens produced an average $61.15-61.58 \mathrm{~g} / \mathrm{egg}$.

Abiola et al. (2008) categorized eggs weight into three size categories: small (41.09-50.97 g), medium (50.98-57.39 g) and large (57.40-69.64 g). An average of $57.20 \mathrm{~g}$ was found in Rhone Island Red Breed according to Monira et al. (2003). Within the strain, there is a connection between the variations in egg weight and in albumen weight. Scott and Silversiders (2000). Administering DPPM on laying strain MB 402 did not affect the eight weight. This is because the available nutrient $\mathrm{RO}$ is less balanced compared to other feed treatments. March and MacMillan (1990) reported that egg size was influenced by the composition of feed fat. Lionoleic fatty acids were needed as part of lipoprotein complex to synthesize egg follicles with the stimulation the estrogen.

Table 2 showed that the weight of egg yolk produced by birds fed with RO (0\%) was significanlty differ from R4 (12\%). Egg yolk produced by birds fed with R4 is more yellow compared to RO (without DPPM). According to Yangtui et al. (2013), internal egg quality

Table 2. Egg Quality from laying hens fed on a dried papaya peel meal diet

\begin{tabular}{llllllll}
\hline Variables & $0 \%$ DPPM & $3 \%$ DPPM & $6 \%$ DPPM & $9 \%$ DPPM & $12 \%$ DPPM & SEM & P Value \\
\hline Egg Weight (g/bird) & $55.38 \pm 0.30$ & $46.25 \pm 22.95$ & $56.19 \pm 0.10$ & $56.74 \pm 0.48$ & $56.72 \pm 0.47$ & 2.04 & .449 \\
Egg Yolk Weight (g) & $14.31 \pm 0.68^{\mathrm{a}}$ & $14.76 \pm 0.10^{\mathrm{a}}$ & $14.85 \pm 0.35^{\mathrm{a}}$ & $15.09 \pm 0.35^{\mathrm{b}}$ & $15.52 \pm 0.45^{\mathrm{b}}$ & .113 & .005 \\
Yolk Index (\%) & $0.46 \pm 0.0$ & $0.46 \pm 0.17$ & $0.45 \pm 0.16$ & $0.45 \pm 0.00$ & $0.45 \pm 0.00$ & .002 & .127 \\
Albumen Index (\%) & $0.44 \pm 0.07$ & $0.45 \pm 0.10$ & $0.44 \pm 0.03$ & $0.43 \pm 0.17$ & $0.44 \pm 0.13$ & .010 & .989 \\
Egg Yolk Color & $7.40 \pm 0.23^{\mathrm{a}}$ & $8.39 \pm 0.36^{\mathrm{b}}$ & $8.53 \pm 0.22^{\mathrm{b}}$ & $8.86 \pm 0.77^{\mathrm{c}}$ & $9.17 \pm 0.38^{\mathrm{d}}$ & .132 & .000 \\
\hline abcd values in the same rows followed with different letters are signicant at $1 \%(\mathrm{P}<0,01)$
\end{tabular}


characteristics, such as height of albumen was not significantly affected, while egg weight and egg shell thickness was significanlty affected by dietary treatments. This argument is supported by Grobas et al. (2001), Senkoylu et al. (2004), and Bohnzack et al. (2007) when they showed that diets that have unsaturated fatty acids in them (which are more easily absorbed into the portal blood) may supply a readily available source of lipid for direct deposition in egg yolk which may help in increasing egg weight, or on the other hand, increase the energy intake through oil addition rather than the increased oil content of the diet.

The color of egg yolk in R4 increased Table 2. The higher the yolk color value shows the yolk is getting yellow to orange, and vice versa. The main factor that affects the color of the yolk is the pigment contained in its constituent feed ingredients. Some feed ingredients contain pigments that may affect the color of egg yolk are ingredients that contain high enough pro vitamin A, for example papaya peel. Murharlien and Nurgiartiningsih (2015) stated that papaya leaf waste in the form of flour and juice $(0 \%, 4 \%$, and $8 \%$ ) did not affect significanlty the feed consumption, egg weigth, ration convertion, number of eggs laid, hen day production (HDP), and shell thickness, but improve the color of the yolk and income over feed cost (IOFC). Yunita et al. (2014) showed that administration of papaya leaf flour on laying quail rations to a level of $6 \%$ could reduce the production and the weight of quail eggs. Therefore after a long egg period, the hen skin tissue became pale or bluish white. Widjastuti (2009) stated in her research that administration of papaya leaves up to $10 \%$ did not show negative effect on eggs production, egg qualities (egg weight, Haugh unit value, yolk index, yolk color score, and shell thickness), however increased the color of yolk.

The observed values were not significant (Table 3). The average egg protein content in the control egg laying hens was $11.05 \%$ And this level increased by $12.25-12.86 \%$ In the eggs of hen supplemented with papaya peel

Table 3. Proximate composition (\%) and cholesterol content $(\mathrm{mg} / 100 \mathrm{~g})$ in egg laying hens

\begin{tabular}{|c|c|c|c|c|c|c|c|}
\hline Variables & 0\% DPPM & $3 \%$ DPPM & 6\% DPPM & 9\% DPPM & $12 \%$ DPPM & SEM & P Value \\
\hline Egg Crude & $11.05 \pm 0.47$ & $12.25 \pm 0.28$ & $12.57 \pm 0.19$ & $12.38 \pm 0.48$ & $12.86 \pm 0.13$ & .141 & .000 \\
\hline Protein (\%), & & & & & & & \\
\hline $\begin{array}{l}\text { Egg Crude Fat } \\
(\%)\end{array}$ & $19.93 \pm 0.45^{a}$ & $19.89 \pm 0.93^{b}$ & $20.31 \pm 0.43^{b}$ & $19.32 \pm 0.6^{b}$ & $17.94 \pm 0.52^{c}$ & .204 & .000 \\
\hline $\begin{array}{l}\text { Egg White } \\
\text { Crude protein } \\
(\%)\end{array}$ & $14.41 \pm 0.14$ & $14.27 \pm 0.98$ & $14.42 \pm 0.14$ & $14.31 \pm 0.92$ & $14.47 \pm 0.34$ & .037 & .453 \\
\hline $\begin{array}{l}\text { Egg Yellow Fat } \\
(\%)\end{array}$ & $31.03 \pm 0.54^{a}$ & $30.43 \pm 0.17^{b}$ & $30.43 \pm 0.15^{b}$ & $30.07 \pm 0.5^{b}$ & $28.64 \pm 0.09^{a}$ & .176 & .000 \\
\hline $\begin{array}{l}\text { Egg Cholesterol } \\
(\mathrm{mg} / 100 \mathrm{~g})\end{array}$ & $212.00 \pm 2.7^{a}$ & $209.20 \pm 3.9^{a}$ & $203.80 \pm 5.3^{b}$ & $198.00 \pm 4 .^{c}$ & $206.00 \pm 0.8^{b}$ & 1.197 & .000 \\
\hline $\begin{array}{l}\text { Egg Shell } \\
\text { Calcium (\%), }\end{array}$ & $28.84 \pm 0.77^{a}$ & $28.48 \pm 1.53^{a}$ & $30.06 \pm 0.50^{b}$ & $30.40 \pm 1.2^{c}$ & $31.13 \pm 0.80^{c}$ & .276 & .003 \\
\hline $\begin{array}{l}\text { Egg Shell } \\
\text { Phosphor (\%) }\end{array}$ & $0.54 \pm 0.08^{a}$ & $0.46 \pm 0.05^{b}$ & $0.54 \pm 0.02^{\mathrm{a}}$ & $0.47 \pm 0.01^{b}$ & $0.53 \pm 0.04^{\mathrm{a}}$ & .011 & 0.36 \\
\hline
\end{tabular}


Table 4. Serum Metabolites of Eggs

\begin{tabular}{|c|c|c|c|c|c|c|c|}
\hline Variables & 0\% DPPM & $3 \%$ DPPM & $6 \%$ DPPM & $9 \%$ DPPM & $12 \%$ DPPM & SEM & $\begin{array}{l}\mathrm{P} \\
\text { Value }\end{array}$ \\
\hline $\begin{array}{l}\text { Blood } \\
\text { Cholesterol } \\
(\mathrm{mg} / \mathrm{dl})\end{array}$ & $112.40 \pm 13.12^{\mathrm{a}}$ & $100 \pm 10.38^{b}$ & $108.4 \pm 5.89^{b}$ & $101.03 \pm 6.13^{b}$ & $98.76 \pm 0.25^{c}$ & 1.89 & 0.08 \\
\hline $\begin{array}{l}\text { Blood LDL } \\
(\mathrm{mg} / \mathrm{dl})\end{array}$ & $120.2 \pm 0.11$ & $118.7 \pm 4.57$ & $115.7 \pm 4.56$ & $116.7 \pm 4.12$ & $112.7 \pm 5.62$ & 1.90 & 0.09 \\
\hline $\begin{array}{l}\text { Blood HDL } \\
\text { (mg/dl) }\end{array}$ & $104.5 \pm 3.79^{a b}$ & $100.6 \pm 1.35^{b}$ & $109.1 \pm 2.68^{\mathrm{ab}}$ & $109.3 \pm 6.4^{a}$ & $102.5 \pm 4.31^{\mathrm{ab}}$ & 1.82 & 0.02 \\
\hline
\end{tabular}

meal (DPPM) with $12 \%$. Egg crude protein is a combination of protein contained in egg yolk and albumen. According to Bashir et al. (2015), hybrid chicken produced $3.43 \%$ egg yolk protein and 27.65 egg yolk crude fat. This study showed that egg yellow fat and egg cholesterol level decreased significantly from treatment $3 \%$ DPPM to $12 \%$ DPPM. Yolk has been reported to be a rich contain high level of fat (Bell and Weaver, 2002). Chicken egg yolk has a cholesterol of $213 \mathrm{mg} / \mathrm{mg}$ (USDA. 1991). According Leke at al. (2015), the effect of tomato meal on egg crude protein was found to be $10.28-10.64 \%$, egg fat $7.87-8.41 \%$, egg carbohydrate $1.19-1.49 \%$ and cholesterol of egg $180.44-189.19 \mathrm{mg} / 100 \mathrm{~g}$. Cholesterol levels are also related to high egg production rates. High egg production causes lower cholesterol levels per egg and vice versa. The number and size of eggs produced can also determine the cholesterol content of the egg. Table 4 shows that the DPPM has a very high significant effect on serum metabolites, in which the blood total cholesterol and blood HDL decreased, but did not have any significant effect on blood LDL. The HDL serum level decreased from 104.5 $\mathrm{mg} / \mathrm{dl}$ (R0) to $102.5 \mathrm{ml} / \mathrm{dl}$ (R4), and LDL serum level from 112.7 to $120.2 \mathrm{mg} / \mathrm{dl}$. According to Hardini (2007), administering lemuru fish oil and palm oil caused the LDL serum level of chicken varied from 21.05 to $23.81 \mathrm{mg} / \mathrm{dl}$, HDL from
111.89 to $123.69 \mathrm{mg} / \mathrm{dl}$, and total cholesterol varied from 157.67 to $170.37 \mathrm{mg} / \mathrm{dl}$. According to Basmacioglu and Ergul (2005), the average LDL level of race chicken blood should be lower than $130 \mathrm{mg} / \mathrm{dl}$.

\section{Conclusions}

The research showed that dried papaya peel meal diet can be fed to the layer hens up to $12 \%$ to produce eggs without negative effects on the egg quality.

\section{Acknowledgement}

This research was funded by Lembaga Penelitian dan Pengabdian Masyarakat Univertitas Sam Ratulangi foundation for excellent application of research under Riset Terapan Unggulan Unsrat 2018 grant.

\section{References}

Abiola SS, OO Meeshioye, BO Oyerinde and MA Bamgbose. 2008. Effect of egg size on hatchability of broiler chicks. Archieve Zootec, 57 (217): 8386.

Ahmad Z. 2013. Pre and post-moult productive and reproductive performance egg geometry and meat composotion of four varieties of native Aseel Chicken. [Unpublished doctoral dissertation]. University of Veterinary and Animal Sciences, Lahore. 
Bashir I, PC Ossai, OK Shittu, AN Abubakar and T Caleb. 2015. Comparison of the nutritional value of egg yolk and egg albumin from domestic chicken, Guinea fowl and hybrid chicken. American Journal of Experimental Agriculture, 6 (5): 310-316.

Basmacioglu $\mathrm{H}$, and M Ergul. 2005. Research on the factor affecting cholesterol content and some other characteristics of Eggs in Laying Hens. Turkish Journal of Veterinary Animal Science, 29:157 -164.

Bell and Weaver. 2002. Commercial chicken meat and egg production manual ( $p p$.1119,11241125). Norwell, MA: Kluwer Academic.

Bohnzack CR, RH Hams, VD Merkel and GB Russell. 2002. Performance of commercial layers when fed diets with four levels of corn oil or poultry fat. Journal Applied Poultry Research. 11:68-76.

Dikman BY, and U Saham. 2007. Correlations between breeder age, egg cholesterol content, blood cholesterol, level and hatchability of broiler breeds. British Poultry Science. 48: 98-103.

Genchev, A. 2012. Quality and composition of Japanese quail eggs (Coturnix japonica). Trakia Journal of Science, 10 (2): 91-101.

Grobas S, GG Mateos and J Mendez. 1999. Influence of dietary linoleic acid on production and weight of eggs and egg components in young brown hens. Journal of Applied Poultry Research. 8 (2).

Hassold T, H Hall and P Hunt. 2007. The origin of human aneuploidy: where we have been, where we ar going. Human Molecular Genetic, 16: 203208.

Hardini D, 2007. Long-chain omega fatty acids in eggs and their changes after processing and their effects on blood cholesterol levels of Rattus norvegicus L. Unpublished doctoral dissertation. Universitas Gadjah Mada.

Hunton P. 1987. Laboratory Evaluations of Egg Quality. In : Egg Quality: Current Problems and Recent Advances, RG Wells and CG Belyavin, (Eds.). Poultry Science Symposium, pp:87-102

Küçükyılmaz, KM. Bozkurt, EN. Herken, M Cınar, AU Catlı, E Bintaş and F Cöven, 2012. Effects of rearing systems on performance, egg characteristics and immune response in two layer hen genotype. Asian-Australasian Journal of Animal Science. 25(4): 559-68.
Lalev M. 2013. A comparison of laying performance of egg type strains. Archiva Zootechnica, 16 (2): 59-66.

Leeson S and JD Summers. 2005. Commersial poultry nutrition. 3rd Edn.,Nottinghamn University Books. Publishing Nottingham University Press Manor Farm Church Lane. Thrumptun, Nottingham NG 110 AX England . Pp 123-160

Leke JR, JS Mandey and F Nangoy. 2015. Nutrients and cholesterol of eggs affected by dried tomato meal in laying hens diet. International Journal on Advanced Science, Engineering and Information $\begin{array}{llll}\text { Technology, } 5 & \text { (3): } 178 & -180 .\end{array}$ DOI:10.18517/ijaseit.5.3.522.

March BE and C MacMilan. 1990. Linoleic acid as mediator of egg size. Poultry Science. 69 (1):634639.

Murharlien M and VMA Nurgiartiningsih. 2015. Utilization of papaya leaf waste in the form of flour and juice to improve Arabian chicken production performance. Journal of Life Science. 2(2):93-100.

Monira KN, M Salahuddin and G Miah, 2003. Effect of breed and holting period on egg quality characteristics of chicken. Journal of Poultry Science. 2(4):261-263.

NRC (National Research Council). 1994. Nutrient requirements of poultry. National Academic of Sciences, Washington.

Parmar SNS, MS Thakur, SS Tomar and PVA Pillai. 2006. Evaluation of egg quality traits in indigenous kadaknath breed of poultry. Livestock Research and Rural Development. 18 (9).

Rafieian K, MM Setorki, M Doudi, A Baradaran and H Nasri. 2014. Atherosclerosis: process, indicators, risk factors and new hopes. International Journal of Preventive Medicine, 5(8):927-946.

Roxana G and MG Usturoi. 2012. Effect of storage time and temperature on hen egg quality. LucrăriŞtiinţifice - Seria Zootehnie 57:221-229.

Scott TA and FG Silversiders. 2000. The effect of storage and strain of hen on egg quality. Poultry Science. 79(12):1725-1729.

Senkoylu N, H Akyurek, E Samil and N Yurdakurban. 2004. Performance and egg weight of laying hens led on the diets with various by-products oil from the oilseed extraction refinery. Pakistan Journal of Nutrition. 3(1):38-42. 
Silversiders FG, DR Korver and KL Budgell. 2006. Effect of strain of layer and age at photostimulation on egg quality and bone strength. Poultry Science. 85(7):1136-1144.

Stadelman WJ and OJ Cotteriil. 1977. Egg Science and Technology. The $2^{\text {nd }}$ Edition. The Avi Publ. Co. Inc.

Steel RGD and JH Torrie, 1980. Principles and procedures of statistics: a biometrical approach. McGraw-Hill Book.

SPSS Inc. Released 2007. SPSS for Windows, Version 16.0. Chicago, SPSS Inc.

USDA (The United States Department of Agriculture). 1991. Nutrient Content of Foods Dairy and Egg Products. Handbook 8-1. USDA-ARS.

Veena D, RB Eswara, ME Naga and SAK Azad. 2015. A study on quality traits of chicken eggs collected in and around Gannavaram, Krishna district in different seasons. International Journal of Recent Science and Research 6(9): 6487-6489Widjastuti
T. 2009. The utilization of flour papaya leaves (carica papaya $\mathrm{L}$ ) states in order to increases in the output and quality of chicken eggs sentul. Jurnal Agroland 16(3): 268- 273.

Willett WC. 2012. Dietary fats and coronary heart disease. Journal of Internal Medicine. 272: 13-24. Yannakopoulus AL and AS Tservani-Gousi. 1986. Quality characteristic of quail eggs. British Poultry Science, 27(2):171-176.

Yunita R, W Warnoto and T Suteky. 2014. Effect of giving papaya leaf flour (carica papaya) in rations on the performance (Coturnix coturnix japonica). Jurnal Sains Peternakan Indonesia. 9(1): 41-50. DOI: 10.31186/jspi.id.9.1.41-50.

Yangtui T, FNA Odoi, I Adam and E Gyamera. 2013. Assessment of some performance and egg quality characteristics in Lohmann brown layers fed diets with varying of Palm Kermel Oil Residue (PKOR). International Journal of Advanced Research. 1(6):1-5. 